\title{
Factors associated with being diagnosed with high severity of breast cancer: a population-based study in Queensland, Australia
}

Kou Kou ${ }^{1}$, Jessica Cameron ${ }^{1,2}$, Joanne F Aitken ${ }^{1,3,4,5}$, Philippa Youl ${ }^{6}$, Gavin Turrell ${ }^{7}$, Suzanne Chambers $^{8}$, Jeff Dunn ${ }^{9}$, Chris Pyke ${ }^{10}$, Peter D Baade ${ }^{1,2,11, \S}$

${ }^{1}$ Cancer Council Queensland, Brisbane, Australia

${ }^{2}$ School of Mathematical Sciences, Queensland University of Technology, Brisbane, Australia

${ }^{3}$ School of Public Health, The University of Queensland, Brisbane, Australia.

${ }^{4}$ School of Public Health and Social Work, Queensland University of Technology, Brisbane, Australia

${ }^{5}$ Institute for Resilient Regions, University of Southern Queensland, Brisbane, Australia

${ }^{6}$ Cancer Alliance Queensland, Metro South Hospital and Health Service, Woolloongabba, Australia

${ }^{7}$ Centre for Research and Action in Public Health, Health Research Institute, University of Canberra, Australia

${ }^{8}$ Faculty of Health, University of Technology Sydney, Sydney, Australia

${ }^{9}$ Prostate Cancer Foundation of Australia, Sydney, Australia

${ }^{10}$ Mater Hospitals South Brisbane, Brisbane, Australia

${ }^{11}$ Menzies Health Institute Queensland, Griffith University, Gold Coast Campus, Parklands Drive, Southport QLD, Australia

\section{§ Corresponding Author}

Prof Peter D Baade-Senior Research Fellow

Cancer Council Queensland-PO Box 201-Spring Hill QLD 4001 Australia

Email: peterbaade@ cancerqld.org.au

Fax: +61 73259 8527; Phone: +61 736345317 


\section{Abstract}

Purpose: This study explores factors that are associated with the severity of breast cancer (BC) at diagnosis.

Methods: Interviews were conducted among women $(\mathrm{n}=3,326)$ aged 20-79 diagnosed with BC between 2011-2013 in Queensland, Australia. High-severity cancers were defined as either Stage II-IV, Grade 3, or having negative hormone receptors at diagnosis. Logistic regression models were used to estimate odds ratios (ORs) of high severity BC for variables relating to screening, lifestyle, reproductive habits, family history, socioeconomic status, and area disadvantage.

Results: Symptom-detected women had greater odds ( $\mathrm{OR}=3.38,2.86-4.00)$ of being diagnosed with high-severity cancer than screen-detected women. Women who did not have regular mammograms had greater odds $(\mathrm{OR}=1.78,1.40-2.28)$ of being diagnosed with highseverity cancer than those who had mammograms biennially. This trend was significant in both screen-detected and symptom-detected women. Screen-detected women who were nonsmokers ( $\mathrm{OR}=1.77,1.16-2.71)$, postmenopausal ( $\mathrm{OR}=2.01,1.42-2.84)$, or employed $(\mathrm{OR}=1.46,1.15-1.85)$ had greater odds of being diagnosed with high-severity cancer than those who were current smokers, premenopausal, or unemployed.

Symptom-detected women being overweight ( $\mathrm{OR}=1.67,1.31-2.14)$, postmenopausal $(\mathrm{OR}=2.01,1.43-2.82)$, had hormone replacement therapy $(\mathrm{HRT})<2$ years $(\mathrm{OR}=1.60,1.02$ 2.51) had greater odds of being diagnosed with high-severity cancer than those of healthy weight, premenopausal, had HRT >10 years.

Conclusion: Screen-detected women and women who had mammograms biennially had lower odds of being diagnosed with high-severity breast cancer, which highlighted the benefit of regular breast cancer screening. Women in subgroups who are more likely to have more severe cancers should be particularly encouraged to participate in regular mammography screening. 


\section{Introduction}

Breast cancer (BC) survival has improved over the past decades in Australia [1,2], largely due to improvements in early detection and treatment [3]. However, those diagnosed with advanced disease still have relatively lower survival [4].

Lower survival is largely attributed to greater severity of cancer at diagnosis, including later stage, higher grade, or negative hormone receptors (HR-) [4-8]. An Australian study reported that women who lived in disadvantaged areas or areas with longer travel time to health facilities were more likely to be diagnosed with advanced BC [9]. Since most of the studies however used population-based cancer registry data, the results were restricted by the limited individual-level information available. Therefore, it remains unclear which individual-level factors are related to higher severity of $\mathrm{BC}$ at diagnosis in the Australian population.

International studies report that individual factors such as older age [10], obesity [11], no family history of BC [12], being unmarried [13], lower education or income [14-16] are associated with a more advanced stage at diagnosis of BC. In Australia, the BreastScreen Program invites women aged 50-74 to undergo free mammograms every two years, with women aged 40-49 also eligible to be screened but not actively invited [17]. In addition, women with higher risk of $\mathrm{BC}$ are encouraged to have an individualised surveillance program developed in consultation with their doctors [18]. While these programs should, in theory, reduce the association between individual-level socioeconomic status (SES) and severity at diagnosis, participation in these programs by Australian women in the target age group is relatively low, around 50\% [19]. Therefore, the strength of the association between individual-level SES and severity at diagnosis in the Australian population remains unclear.

This study uses a large, population-based cohort of women diagnosed with BC in Queensland (Australia) to explore individual and area-level factors associated with high severity of BC at diagnosis. Identification of modifiable factors has the potential to inform interventions to reduce the likelihood of high-severity disease at diagnosis and, in doing so, improve survival and other outcomes. 


\section{Methods}

Ethical approval was obtained from the Human Research Ethics Committee of Griffith University, Australia (PSY/C4/09/HREC).

\section{Study population}

The Breast Cancer Outcomes Study (BCOS) [20,21] is a longitudinal study among women aged 20 to 79 years diagnosed with invasive BC in Queensland, Australia between 1 January 2011 and 30 June 2013. In total, 5426 eligible women were identified for a telephone interview. Among these, 66 were deceased and 688 were not consented by their doctor. Of the remaining 4672 women with doctor consent, 3326 (71.2\%) completed the interview. There was no evidence of a difference in age distribution between participants and nonparticipants $(\mathrm{p}=0.33)$, however women living in major cities $(\mathrm{p}=0.04)$ and diagnosed with advanced disease $(\mathrm{p}=0.03)$ were less likely to participate. More details on study population and recruitment can be found in a previous publication [21].

\section{Data collection}

Full details of data collection have been described previously [20,21]. Briefly, a validated, semi-structured telephone interview administered by trained health interviewers was used to collect details such as each women's pathway to diagnosis, socio-demographic information and medical history, with additional clinical information extracted from medical records. The telephone interview was conducted prior to the completion of the self-administered questionnaire. These were completed within three years after diagnosis, with half of the participants returning their questionnaire within 391 days (time interval between diagnosis and the returning of self-administered questionnaire ranged from 93 to 923 days, interquartile range from 276 to 890 days) (Supplementary Figure 1).

Participants were classified into two groups: symptom detected and screen detected. Those detected by symptoms were women whose first sign or symptom of BC was initially noticed by themselves, a doctor, or a layperson. The screen detected group represented women where the suspicion of BC was made via routine mammography or ultrasound [21]. 


\section{Individual-level information}

Individual-level information were collected about the time before diagnosis (Table 1) including frequency of having mammograms, lifestyle (such as BMI, physical activity), reproductive history (such as age at menarche, menopause status), family history of breast and ovarian cancer, SES (such as education, employment, gross household income, health insurance status), and residential location. In Australia, individuals who pay for private health insurance avoid the typically longer waiting times associated with treatment in the public hospital system and have their choice of treating doctors [22].

Clinical coders extracted relevant data items from histopathology reports including age at diagnosis, tumour site and size, morphology, histological grade, degree of lymph node involvement, estrogen, progesterone and Herceptin status. Cancer stage was assigned by the clinical coders according to the current American Joint Committee Cancer Staging Manual at time of coding [23].

\section{Area-level information}

The geographical unit of analysis was the Statistical Area Level 2 (SA2), as defined by the 2011 Australian Statistical Geography Standard (ASGS) classification system [20]. The SA2s were designed to be relatively homogeneous in terms of the socioeconomic characteristics of the populations they contain [20].

Each participant was assigned to an SA2 based on their residential address at cancer diagnosis. Area-level factors were geographic remoteness, accessibility to treatment, and area-level SES (Table 1). Remoteness was designated using the ASGS Remoteness Areas [24]. Four categories of remoteness ("Major city", "Inner regional”, "Outer regional” and "Remote/very remote") were determined by access to services. We combined the categories "Outer regional" and "Remote/very remote" to allow sufficient numbers for analyses. Accessibility to treatment was classified based on the road travel time from their residential SA2 to the closest radiation facility (high: $<1 \mathrm{~h}$, low $\geq 1 \mathrm{~h}$ ) [25]. Area-level SES was measured using the 2011 Index of Relative Socioeconomic Disadvantage (IRSD), a censusbased aggregated measure that summarises information about the economic and social conditions of people and households within a SA2 [21]. While the IRSD is normally reported in Quintiles, for this study the quintiles were collapsed into three groups as 'most 
disadvantaged (Quintile 1)', 'middle SES (Quintile 2-4)', and 'least disadvantaged (Quintile 5)', to increase the numbers in each category.

\section{Outcome measures}

Three histopathological factors associated with BC survival [4-8] were selected to represent the severity of $\mathrm{BC}$ at diagnosis including stage, grade, and hormone receptors status. We recategorized the stage outcome into two categories (stage I or stage II-IV) to ensure enough observations for analysis. For the same reason, we also recategorized the grade outcome into two categories (Grade 1-2 or Grade 3). Previous studies have suggested that women with BC with both estrogen receptor negative (ER-) and progesterone receptor negative (PR-) had lower survival $[26,27]$. Therefore, the hormone receptors status outcome was categorised as hormone receptor negative (HR-, neither of the hormone receptors positive) or hormone receptor positive (HR+, with one or both the hormone receptors positive).

Since the three outcome variables were correlated, with the Pearson correlation between hormone receptors status and grade being 0.43 , stage and grade being 0.23 , we generated a new outcome representing the overall severity of $\mathrm{BC}$ at diagnosis by combining the three outcome variables. The overall severity outcome was categorised into high severity and low severity, with high severity cancers representing those diagnosed with either stage II-IV, Grade 3, or HR- cancer; and low severity cancers being those diagnosed with stage I, grade 12 and HR+ cancer.

\section{Statistical analysis}

While the hierarchical structure of the data (individual level and area level) suggested a multilevel model, our initial analysis using a multilevel logistic regression on the binary outcome variables showed that the variance of the random intercept at the SA2 level was almost zero. This suggested all the geographic variations of the outcome variable was accounted for by the fixed effects, the multilevel model gave the same result as an individual level model. Therefore, we used individual-level logistic regression models for the four outcome variables.

Logistic regression models were developed for each of the outcome variables including stage (Model 1), grade (Model 2), hormone receptors status (Model 3), and the overall severity (Model 4) to determine the factors associated with each outcome. All the models were adjusted for age and method of detection. For the overall severity outcome, another two 
models stratified by the methods of detection (Model 5 (screen detected) \& 6 (symptoms detected)) were developed to see if the influential factors for the overall severity outcome were different between symptom-detected and screen-detected women. In addition, a further analysis stratified the screen-detected women into those screened in public facilities (Model 7) and those screened in private facilities (Model 8) were conducted for the overall severity outcome.

The models were developed using a backward stepwise method [28]. All the available factors (listed in Table 1) were included in the model initially. A likelihood ratio test was used to drop variables with a p-value $>0.2$. At each step, variables previously removed from the model were tested to gauge their eligibility to be re-included into the model.

\section{Multiple imputation}

Missing data ranged from $0-11.7 \%$ for predictor or outcome variables (Table 1), and a complete case analysis would have excluded $34 \%$ of the initial cohort, potentially introducing a bias if the excluded cases were a non-random sample. Missing data were handled with multiple imputation methods [29], using the mi impute chained and mi estimate commands for chained equations and subsequent regression model estimation. In the imputation modelling we included auxiliary variables that are correlated with missing variables (Pearson correlation > 0.4). All variables included in the final models were also included in the series of chained imputation equations. We used 34 imputations based on the percentage of incomplete cases [30].

All statistical analyses were performed using Stata/SE version 16 (StataCorp, TX, USA).

\section{Results}

Among the 3326 participants who completed the interview, 59 did not have stage information, 45 did not have grade, and 106 did not have hormone receptors status, resulting in 167 for whom severity could not be determined. Among those women who had values for the outcome variables, $1666(51.0 \%, \mathrm{n}=3267)$ were diagnosed with stage II-IV BC, 1076 $(32.8 \%, \mathrm{n}=3281)$ were grade 3 cancer, $439(13.6 \%, \mathrm{n}=3220)$ were HR-, and $1981(62.7 \%$, $\mathrm{n}=3159$ ) were categorised as having high severity cancer (Table 1 ). 


\section{Stage, grade, and hormone receptors}

Women whose $\mathrm{BC}$ was detected by symptoms were associated with 3.63 times higher odds of being diagnosed with stage II-IV BC, 2.25 times higher odds of being diagnosed with grade 3 cancer, and 2.42 times higher odds of being diagnosed with HR-cancer than those detected by screening (Table 2). Those who were diagnosed before 50 years of age were more likely to have stage II-IV and grade 3 cancer than those diagnosed after 70.

The other factors significantly associated with each of stage, grade, and hormone receptor status were similar with consistent patterns (Table 2). For the stage outcome, women who did not have biennial screening mammograms, were overweight, never smoked, postmenopausal, or not fully insured had higher odds of being diagnosed with stage II-IV cancers. For the grade outcome, not having mammograms biennially, never having smoked, duration of menstruation $\leq 35$ years, postmenopausal, duration of contraceptives use $\geq 2$ years, no firstdegree family history of breast or ovarian cancer, or lived in inner regional areas had higher odds of being diagnosed with grade $3 \mathrm{BC}$. For the hormone receptors status outcome, higher odds of being diagnosed with HR-cancer was observed for women who never smoked and whose duration of menstruation was $\leq 35$ years.

\section{Overall severity}

Women with symptom-detected BC were associated with 3.38 times higher odds of being diagnosed with high severity BC than those detected by screening (Figure 1). Not having mammograms biennially, younger age, being overweight, never having smoked, being postmenopausal, or not being fully privately insured were associated with greater odds of high severity cancer at diagnosis (Figure 1).

When stratified by methods of detection, around $40 \%-50 \%$ of the screen-detected women were diagnosed with high severity cancer, while the corresponding numbers for the symptom-detected women were around 70\%-80\% (Table 3). Although screen-detected and symptom-detected women had different proportions of high severity cancer, the magnitude and direction of the covariate effects were largely the same for most variables except employment status (Figure $1 \&$ Table 3). For screen-detected cancers, women who were employed had greater odds of being diagnosed with high severity cancer; while for symptomdetected cancers, women who were employed tended to have lower odds of being diagnosed with high severity cancer (Figure $1 \&$ Table 3 ). 
Further stratification of the screen-detected women into those screened in public facilities $(n=1233)$ and those screened in private facilities $(n=409)$ (Supplementary Table 1) showed that among those screened in private facilities, employed women had greater odds of being diagnosed with high severity cancer than the unemployed $(\mathrm{OR}=2.24, \mathrm{p}<0.01)$, and women not fully covered by private insurance were more likely to be diagnosed with high severity cancer than those fully insured $(\mathrm{OR}=2.10, \mathrm{p}=0.01)$. However, there was no significant evidence of independent effects of employment status $(\mathrm{OR}=1.29, \mathrm{p}=0.07)$ and insurance status $(\mathrm{OR}=1.09, \mathrm{p}=0.50)$ among women who did their screening in public facilities.

\section{Discussion}

This study identified several individual and geographic factors associated with greater odds of being diagnosed with high severity BC. Women with screen-detected BC were less likely to be diagnosed with high severity cancer than those with symptom-detected BC. After adjusting for the method of detection, women who did not have regular mammograms had greater odds of being diagnosed with high severity cancer than those who had biennial mammograms. In addition, most of the factors associated with a higher risk of being diagnosed with breast cancer were associated with lower odds of being diagnosed with a high severity BC. Except for employment status, the direction and strength of the associations were similar between screen-detected and symptom-detected women.

Screen-detected women who were employed had $46 \%$ greater odds of being diagnosed with high severity cancer. The findings were independent of age at diagnosis. Possible explanations might include unmeasured barriers making it difficult for employed women to get mammograms in time and/or causing delays in definitive diagnosis after mammograms. Australian studies have reported employed migrants had lower annual clinical breast examination than unemployed migrants [31], and women with more time pressure were less likely to have mammograms than those with less time pressure [32]. However, since our model adjusted for the frequency of mammography screening, the potential barriers of getting mammograms among employed women might not be their main reason for having more severe cancer than the unemployed.

When stratifying the screen-detected women by public or private screening facilities, the employment effect was only visible among those screened in private facilities, while the 
effect was not significant among women whose mammogram was in a public facility. Further exploration of this counter intuitive result is warranted.

Lower individual- or area-level SES has been linked to poorer BC survival in different countries [33-38] including Australia [39]. Studies have attributed this finding to more advanced stages of cancers at diagnosis and more limited treatment, with suggested reasons varying with the country and health system characteristics [40-44]. In Australia, as in our study, women from more disadvantaged areas have been shown to be more likely to be diagnosed with advanced BC [9] while other Australian studies have shown they also have less access to specialists and received suboptimal treatments $[44,45]$.

In terms of individual-level SES, we found that except for employment status, there was no evidence that other SES factors such as education, insurance status, income, number of cars, marital status, and language spoken at home having a significant independent association with severity at diagnosis. Apart from employment status, the lack of significant associations with SES among screen-detected participants may reflect the impact of the BreastScreen Program in providing free access to mammography screening for all Australian women aged 50-74 years [46], along with BC awareness campaigns [47,48]. The results suggested that in Australia, the influence of individual SES on BC survival [49] might be less attributable to pre-diagnosis factors but mainly attributable to post-diagnosis factors such as the period between diagnosis and treatment or different treatment options.

Women with higher SES have been reported to have higher incidence of HR+ subtypes of breast cancer compared with lower SES, possibly related to the higher levels of circulatory hormones as a result of their predominant reproductive patterns such as earlier menarche, lower parity and later age at first birth [50-52]. However, we did not find a strong association between hormone receptor status at diagnosis and SES factors.

We found that most of the established risk factors for being diagnosed with $\mathrm{BC}$ such as older age, smoking, longer duration of menstruation, use of HRT, and family history of breast and ovarian cancer [53-56] were associated with a lower odds of being diagnosed with high severity BC. Some of this might be explained by a higher awareness of BC among high-risk participants. For example, an Australian study reported that women with a family history of $\mathrm{BC}$ were more likely to overestimate their risk of having BC [57], and screening participation rates are reported to be higher among older women than younger women [19]. However, the 
higher severity among younger patients may also be a function of tumour biology, in that while younger women have a lower incidence of $\mathrm{BC}$, they are also more likely to have more aggressive tumours [58] and less likely to be detected early due to their higher breast density [59]. Even though population-based mammography screening is not recommended for younger women, alternative methods of identifying these cancers earlier including conducting breast self-examination monthly and clinical breast examination yearly by family physician [32] should be encouraged especially among subgroups with higher odds of being diagnosed with high severity cancer.

It is likely that at least some of the differential in severity between screen-detected and symptom-detected cancers is due to the propensity for length-time bias and overdiagnosis associated with mammography screening [60]. Since women were screened at a certain point in time, those with slow-growing (low severity) disease were more likely to be detected by screening while more aggressive (high severity) cancers tend to be detected after having symptoms (length-time bias) during the screening intervals [61]. Length-time bias is related to overdiagnosis, as screening tends to detect slower-growing cancers that would never have caused harm to the patients had they remained undetected [62]. However, it is also reasonable to suggest that the likelihood of length-time bias and overdiagnosis would be consistent within each of the screen-detected and symptom-detected cohort, providing greater confidence that the differences observed within each of these strata reflect true differences.

Study strengths include the use of a large cohort of women ascertained through a populationbased cancer registry, which may strengthen the potential generalizability of the findings. In addition, the use of individual level variables which are not available in cancer registry data enables us to explore the association between area SES and individual factors simultaneously. Further, participants were stratified by detection method and thus the different impacts of the influential factors on the severity of BC detected by screening or symptoms were elucidated. Further, multiple imputation was used to enable all participants to be included into the final analysis, thus reducing the potential for additional biases by excluding records with missing data.

The retrospective nature of this study increases the potential for inaccuracies in how information such as reproductive history behaviours were provided. In order to evaluate the accuracy of the information, respondents were asked "How accurate is this age?" after questions like “At what age did you first get your periods?". From these data, more than 95\% 
of participants were confident about their menstruation history; more than $90 \%$ of participants stated the accuracy for their contraceptive use history was within two years; and more than $85 \%$ stated that the accuracy of their HRT histories was within two years.

\section{Conclusion}

This study identified important factors associated with being diagnosed with high severity BC. Although the screening-related biases should be considered, the significantly lower odds of screen-detected cancers being more severe, and the lower odds of women who have regular mammograms being diagnosed with more severe cancers, supports the effective role of regular screening in early detection. The finding of a greater odds of high severity BC among screen-detected women who were employed requires further investigation. Women in population subgroups that are more likely to have higher proportion of severe cancers should be particularly encouraged to participate in mammography screening. 
Table 1 Observed percentages of breast cancer diagnosed with late stage, high grade, negative hormone receptors, or overall high severity by different factors.

\begin{tabular}{|c|c|c|c|c|c|}
\hline & \multirow{2}{*}{ No. women (\%) } & \multicolumn{4}{|c|}{ Percentages (95\% $\mathrm{CI}^{1}$ ) } \\
\hline & & Stage II-IV ${ }^{2}$ & Grade $3^{3}$ & $\mathrm{HR}_{-}{ }^{4}$ & High severity $^{5}$ \\
\hline All & $3,326(100)$ & $51.0(49.3-52.7)$ & $32.8(31.2-34.4)$ & $13.6(12.4-14.8)$ & $62.7(61.0-64.4)$ \\
\hline \multicolumn{6}{|l|}{ Method of detection } \\
\hline Screening & $1,642(49.4)$ & $33.8(31.5-36.1)$ & $22.5(20.5-24.5)$ & $8.7(7.4-10.1)$ & $47.5(45.0-49.9)$ \\
\hline Symptoms & $1,684(50.6)$ & $68.3(66.0-70.5)$ & $43.0(40.6-45.4)$ & $18.5(16.6-20.4)$ & $78.2(76.1-80.2)$ \\
\hline \multicolumn{6}{|c|}{ Frequency of screening } \\
\hline At least two-yearly & $2,276(68.4)$ & $43.2(41.2-45.3)$ & $28.6(26.7-30.4)$ & $13.0(11.6-14.4)$ & $56.0(53.9-58.0)$ \\
\hline Infrequently & $499(15.0)$ & $65.8(61.6-70.0)$ & $39.8(35.4-44.1)$ & $15.6(12.3-18.8)$ & $76.4(72.6-80.3)$ \\
\hline None & $549(16.5)$ & $70.2(66.3-74.1)$ & $44.2(40.0-48.4)$ & $14.5(11.5-17.5)$ & $78.9(75.3-82.4)$ \\
\hline Unknown & $2(0.1)$ & $50.0(0.0-100.0)$ & $50.0(0.0-100.0)$ & $0.0(-)$ & $50.0(0.0-100.0)$ \\
\hline \multicolumn{6}{|l|}{ Age of diagnosis } \\
\hline$<50$ & $897(27.0)$ & $60.8(57.6-64.0)$ & $43.0(39.7-46.2)$ & $15.7(13.2-18.1)$ & $72.5(69.5-75.6)$ \\
\hline $50-59$ & $946(28.4)$ & $52.5(49.3-55.7)$ & $32.5(29.5-35.5)$ & $14.3(12.1-16.6)$ & $63.9(60.8-67.1)$ \\
\hline $60-69$ & $1,026(30.9)$ & $43.3(40.3-46.4)$ & $26.8(24.1-29.6)$ & $12.1(10.1-14.2)$ & $55.7(52.6-58.8)$ \\
\hline $70-79$ & $457(13.7)$ & $45.9(41.2-50.6)$ & $26.9(22.8-31.0)$ & $11.6(8.6-14.6)$ & $56.8(52.1-61.5)$ \\
\hline \multicolumn{6}{|l|}{ Lifestyle } \\
\hline \multicolumn{6}{|l|}{ BMI $^{6}$} \\
\hline Healthy weight & $1,292(38.9)$ & $48.6(45.8-51.3)$ & $33.0(30.5-35.6)$ & $14.1(12.1-16.0)$ & $60.5(57.8-63.2)$ \\
\hline Overweight & $2,034(61.2)$ & $52.5(50.3-54.7)$ & $32.6(30.6-34.7)$ & $13.4(11.9-14.9)$ & $64.1(62.0-66.3)$ \\
\hline \multicolumn{6}{|l|}{ Physical activity } \\
\hline Insufficient & $1,444(43.4)$ & $51.7(49.1-54.3)$ & $31.7(29.2-34.1)$ & $13.1(11.3-14.9)$ & $62.7(60.1-65.2)$ \\
\hline Sufficient & $1,835(55.2)$ & $50.7(48.4-53.0)$ & $33.6(31.5-35.8)$ & $14.1(12.5-15.7)$ & $63.1(60.8-65.3)$ \\
\hline Unknown $^{7}$ & $47(1.4)$ & $40.4(26.2-54.6)$ & $34.0(20.3-47.7)$ & $12.8(3.1-22.4)$ & $51.1(36.6-65.5)$ \\
\hline \multicolumn{6}{|l|}{ Smoking } \\
\hline Current smoker & $226(8.0)$ & $51.5(45.5-57.6)$ & $31.7(26.1-37.3)$ & $11.9(7.9-15.8)$ & $63.0(57.1-68.9)$ \\
\hline Used to smoke & $1,169(35.2)$ & $49.5(46.6-52.4)$ & $31.7(29.0-34.4)$ & $12.1(10.2-14.0)$ & $60.8(57.9-63.7)$ \\
\hline Never smoked & $1,886(56.7)$ & $51.9(49.6-54.1)$ & $33.6(31.5-35.8)$ & $14.9(13.2-16.5)$ & $63.9(61.6-66.1)$ \\
\hline Unknown & $5(0.2)$ & $40.0(0.0-88.0)$ & $40.0(0.0-88.0)$ & $0.00(-)$ & $60.0(12.0-100.0)$ \\
\hline \multicolumn{6}{|l|}{ Drinking } \\
\hline$<$ Once a month & $1,293(38.9)$ & $52.0(49.3-54.8)$ & $31.3(28.7-33.8)$ & $13.5(11.6-15.4)$ & $63.0(60.3-65.7)$ \\
\hline$\geq$ Once a month & $2,033(61.1)$ & $50.3(48.2-52.5)$ & $33.7(31.7-35.8)$ & $13.7(12.2-15.2)$ & $62.5(60.4-64.7)$ \\
\hline \multicolumn{6}{|l|}{ Reproductive history } \\
\hline \multicolumn{6}{|l|}{ Age at menarche } \\
\hline$\leq 13$ & $2,160(64.9)$ & $51.9(49.8-54.0)$ & $32.4(30.4-34.4)$ & $13.5(12.0-14.9)$ & $63.2(61.2-65.3)$ \\
\hline$>13$ & $1,131(34.0)$ & $49.6(46.7-52.6)$ & $33.6(30.8-36.4)$ & $14.2(12.2-16.3)$ & $62.0(59.1-64.9)$ \\
\hline Unknown & $35(1.05)$ & $38.2(21.7-54.8)$ & $31.4(15.8-47.0)$ & $5.7(0.0-13.5)$ & $52.9(35.9-70.0)$ \\
\hline \multicolumn{6}{|c|}{ Duration of menstruation } \\
\hline$\leq 35$ years & $1,639(49.3)$ & $54.2(51.8-56.6)$ & $38.3(35.9-40.7)$ & $15.6(13.8-17.3)$ & $67.1(64.7-69.4)$ \\
\hline$>35$ years & $1,601(48.1)$ & $48.2(45.7-50.7)$ & $27.3(25.1-29.5)$ & $11.8(10.2-13.4)$ & $58.6(56.1-61.0)$ \\
\hline Unknown & $86(2.6)$ & $41.7(31.1-52.3)$ & $29.1(19.4-38.7)$ & $10.6(4.0-17.2)$ & $56.6(45.9-67.4)$ \\
\hline \multicolumn{6}{|l|}{ Menopause } \\
\hline Yes & 2,691 (80.9) & $51.1(49.2-53.0)$ & $32.3(30.5-34.0)$ & $13.6(12.3-14.9)$ & $62.8(60.9-64.6)$ \\
\hline No & $635(19.1)$ & $50.5(46.6-54.4)$ & $35.1(31.3-38.9)$ & $13.8(11.1-16.5)$ & $62.4(58.6-66.3)$ \\
\hline \multicolumn{6}{|c|}{ Age started using contraceptives } \\
\hline Never used & $413(12.4)$ & $48.6(43.8-53.5)$ & $29.3(24.9-33.7)$ & $11.7(8.6-14.9)$ & $60.4(55.5-65.2)$ \\
\hline$\leq 18$ & $1,062(31.9)$ & $55.5(52.4-58.5)$ & $39.7(36.7-42.7)$ & $16.2(14.0-18.5)$ & $67.4(64.5-70.3)$ \\
\hline$>18$ & $1,835(55.2)$ & $49.0(46.7-51.3)$ & $29.6(27.5-31.7)$ & $12.6(11.1-14.2)$ & $60.7(58.4-62.9)$ \\
\hline Unknown $^{7}$ & $16(0.5)$ & $40.0(14.3-65.7)$ & $26.7(3.5-49.8)$ & $6.3(0.0-18.5)$ & $50.0(22.8-77.2)$ \\
\hline Duration of using cor & & & & & \\
\hline Never or $<2$ years & $688(20.7)$ & $49.0(45.2-52.7)$ & $27.3(24.0-30.7)$ & $11.4(9.0-13.8)$ & $60.6(56.9-64.4)$ \\
\hline 2-10 years & $1,301(39.1)$ & $51.7(48.9-54.4)$ & $33.4(30.8-35.9)$ & $14.5(12.6-16.4)$ & $62.4(59.7-65.1)$ \\
\hline$>10$ years & $1,318(39.6)$ & $51.5(48.7-54.2)$ & $35.1(32.6-37.7)$ & $13.9(12.0-15.8)$ & $64.2(61.6-66.9)$ \\
\hline Unknown $^{7}$ & $19(0.6)$ & $44.4(20.8-68.1)$ & $27.8(6.5-49.1)$ & $15.8(0.0-32.6)$ & $52.9(28.5-77.4)$ \\
\hline Age at first childbirtl & & & & & \\
\hline Never give birth & $112(3.4)$ & $47.3(37.9-56.6)$ & $35.1(26.2-44.1)$ & $16.7(9.6-23.7)$ & $60.4(51.0-69.7)$ \\
\hline$\leq 30$ & $2,358(70.9)$ & $50.4(48.3-52.4)$ & $32.1(30.2-34.0)$ & $13.9(12.5-15.4)$ & $62.1(60.1-64.1)$ \\
\hline$>30$ & $467(14.0)$ & $54.2(49.7-58.8)$ & $32.2(27.9-36.4)$ & $12.9(9.8-16.0)$ & $64.0(59.6-68.5)$ \\
\hline Unknown $^{7}$ & $389(11.7)$ & $52.0(46.9-57.0)$ & $36.8(32.0-41.7)$ & $11.8(8.5-15.0)$ & $65.5(60.6-70.4)$ \\
\hline Number of children & & & & & \\
\hline None & $112(3.4)$ & $47.3(37.9-56.6)$ & $35.1(26.2-44.1)$ & $16.7(9.6-23.7)$ & $60.4(51.0-69.7)$ \\
\hline $1-2$ & $1,554(46.7)$ & $50.6(48.0-53.1)$ & $32.8(30.5-35.2)$ & $14.6(12.8-16.4)$ & $62.3(59.9-64.8)$ \\
\hline$>2$ & $1,660(49.9)$ & $51.7(49.2-54.1)$ & $32.6(30.3-34.9)$ & $12.5(10.9-14.1)$ & $63.2(60.8-65.6)$ \\
\hline
\end{tabular}




\begin{tabular}{|c|c|c|c|c|c|}
\hline \multicolumn{6}{|c|}{ Duration of breastfeeding } \\
\hline None & $957(28.8)$ & $50.2(47.0-53.4)$ & $33.1(30.1-36.0)$ & $13.5(11.3-15.7)$ & $62.5(59.4-65.7)$ \\
\hline $1-12$ months & $1,157(34.8)$ & $50.3(47.4-53.2)$ & $33.0(30.3-35.7)$ & $14.1(12.0-16.1)$ & $61.6(58.7-64.5)$ \\
\hline$>12$ month & $1,212(36.4)$ & $52.3(49.5-55.2)$ & $32.4(29.7-35.0)$ & $13.3(11.4-15.3)$ & $63.9(61.2-66.7)$ \\
\hline \multicolumn{6}{|l|}{${\text { Duration of } \text { HRT }^{8}}^{8}$} \\
\hline Never or $<2$ years & $2,441(73.4)$ & $53.6(51.6-55.6)$ & $35.0(33.1-36.9)$ & $13.9(12.5-15.3)$ & $65.1(63.2-67.1)$ \\
\hline $2-10$ years & $515(15.5)$ & $43.4(39.0-47.7)$ & $27.7(23.8-31.6)$ & $13.0(10.1-16.0)$ & $56.5(52.1-60.9)$ \\
\hline$>10$ years & $290(8.7)$ & $42.3(36.5-48.0)$ & $23.1(18.2-28.0)$ & $10.3(6.7-13.8)$ & $52.3(46.5-58.2)$ \\
\hline Unknown $^{7}$ & $80(2.4)$ & $51.9(40.8-63.0)$ & $34.6(24.0-45.2)$ & $20.3(11.3-29.2)$ & $67.1(56.5-77.7)$ \\
\hline \multicolumn{6}{|l|}{ Family history } \\
\hline \multicolumn{6}{|c|}{ Relatives with breast or ovarian cancer } \\
\hline None & $1,713(51.5)$ & $51.0(48.6-53.4)$ & $34.3(32.0-36.5)$ & $14.0(12.3-15.7)$ & $63.4(61.1-65.8)$ \\
\hline $2^{\text {nd }}$ degree & $686(20.6)$ & $53.9(50.1-57.6)$ & $36.3(32.7-39.9)$ & $16.4(13.6-19.2)$ & $66.6(62.9-70.2)$ \\
\hline $1^{\text {st }}$ degree & $417(12.5)$ & $47.5(42.7-52.4)$ & $24.0(19.9-28.2)$ & $11.4(8.3-14.5)$ & $57.3(52.4-62.2)$ \\
\hline $1^{\text {st }} \& 2^{\text {nd }}$ degree & $332(10.0)$ & $47.5(42.1-53.0)$ & $30.7(25.7-35.7)$ & $10.9(7.5-14.4)$ & $57.2(51.7-62.7)$ \\
\hline Unknown $^{7}$ & $178(5.4)$ & $54.5(47.2-61.8)$ & $29.8(23.0-36.5)$ & $9.7(5.3-14.1)$ & $64.0(56.9-71.1)$ \\
\hline \multicolumn{6}{|l|}{ Individual SES } \\
\hline \multicolumn{6}{|l|}{ Education } \\
\hline$<$ High school & $989(29.7)$ & $47.7(44.5-50.8)$ & $29.7(26.8-32.6)$ & $12.9(10.8-15.1)$ & $60.2(57.0-63.3)$ \\
\hline High school/certificate & $1,102(33.1)$ & $51.9(48.9-54.8)$ & $34.9(32.1-37.7)$ & $14.9(12.8-17.0)$ & $64.3(61.4-67.2)$ \\
\hline$\geq$ Diploma & $1,235(37.1)$ & $52.8(50.0-55.6)$ & $33.4(30.7-36.0)$ & $13.1(11.2-15.0)$ & $63.3(60.5-66.0)$ \\
\hline \multicolumn{6}{|l|}{ Employment } \\
\hline Unemployed/retired & $1,367(41.1)$ & $46.9(44.2-49.6)$ & $28.5(26.1-30.9)$ & $12.5(10.7-14.2)$ & $57.7(55.1-60.4)$ \\
\hline Employed $^{9}$ & $1,941(58.4)$ & $53.9(51.7-56.2)$ & $35.9(33.8-38.1)$ & $14.6(13.0-16.2)$ & $66.3(64.2-68.5)$ \\
\hline Unknown $^{7}$ & $18(0.5)$ & $44.4(20.8-68.1)$ & $22.2(2.5-42.0)$ & $0.0(-)$ & $50.0(26.2-73.8)$ \\
\hline \multicolumn{6}{|l|}{ Income } \\
\hline$<\$ 52,000$ & $1,216(36.6)$ & $49.1(46.2-51.9)$ & $30.0(27.4-32.6)$ & $12.3(10.4-14.2)$ & $60.4(57.5-63.2)$ \\
\hline$\$ 52,000-\$ 129,999$ & $1,271(38.2)$ & $52.1(49.3-54.9)$ & $35.9(33.2-38.5)$ & $15.6(13.6-17.6)$ & $65.2(62.5-67.9)$ \\
\hline$\geq \$ 130,000$ & $476(14.3)$ & $54.9(50.4-59.4)$ & $36.0(31.7-40.4)$ & $12.9(9.8-16.0)$ & $65.9(61.5-70.2)$ \\
\hline Unknown $^{7}$ & $363(10.9)$ & $48.5(43.2-53.7)$ & $27.1(22.5-31.7)$ & $12.0(8.6-15.5)$ & $57.7(52.5-63.0)$ \\
\hline \multicolumn{6}{|l|}{ Number of cars } \\
\hline None & $132(4.0)$ & $53.9(45.2-62.6)$ & $29.2(21.4-37.1)$ & $9.9(4.8-15.1)$ & $65.6(57.4-73.9)$ \\
\hline 1 car & $1,109(33.3)$ & $50.6(47.6-53.6)$ & $30.9(28.2-33.7)$ & $13.6(11.6-15.6)$ & $62.6(59.7-65.5)$ \\
\hline 2 cars & $1,407(42.3)$ & $51.0(48.4-53.7)$ & $32.8(30.3-35.2)$ & $13.8(12.0-15.7)$ & $62.6(60.0-65.2)$ \\
\hline$>2$ cars & $601(18.1)$ & $52.8(48.8-56.8)$ & $37.5(33.6-41.4)$ & $14.1(11.2-16.9)$ & $64.1(60.2-68.1)$ \\
\hline Unknown ${ }^{7}$ & $77(2.3)$ & $36.8(25.9-47.8)$ & $29.3(19.0-39.7)$ & $13.5(5.7-21.4)$ & $51.4(39.8-63.0)$ \\
\hline \multicolumn{6}{|l|}{ Marital status ${ }^{10}$} \\
\hline Married & $2,440(73.4)$ & $50.7(48.7-52.7)$ & $33.7(31.8-35.6)$ & $14.4(13.0-15.8)$ & $62.8(60.8-64.7)$ \\
\hline Not married & $886(26.6)$ & $51.9(48.5-55.2)$ & $30.2(27.1-33.2)$ & $11.4(9.3-13.6)$ & $62.6(59.3-65.8)$ \\
\hline \multicolumn{6}{|c|}{ Language speaks at home } \\
\hline English & $3,149(94.7)$ & $50.9(49.1-52.7)$ & $32.8(31.2-34.5)$ & $13.7(12.5-14.9)$ & $62.6(60.8-64.3)$ \\
\hline Other & $177(5.3)$ & $52.9(45.4-60.3)$ & $32.2(25.2-39.1)$ & $12.8(7.8-17.8)$ & $65.5(58.3-72.7)$ \\
\hline \multicolumn{6}{|l|}{ Private insurance } \\
\hline Full insurance & $2,110(63.4)$ & $47.8(45.6-49.9)$ & $32.8(30.8-34.8)$ & $13.7(12.2-15.2)$ & $60.8(58.6-62.9)$ \\
\hline $\mathrm{No} /$ part insurance & $1,215(36.5)$ & $56.7(53.9-59.5)$ & $32.9(30.2-35.5)$ & $13.5(11.5-15.4)$ & $66.2(63.5-69.0)$ \\
\hline Unknown $^{7}$ & $1(0.0)$ & $0.00(-)$ & $0.00(-)$ & $0.0(-)$ & $0.0(-)$ \\
\hline \multicolumn{6}{|l|}{ Area-level factors } \\
\hline \multicolumn{6}{|l|}{ Remoteness } \\
\hline Major city & $1,969(59.2)$ & $49.8(47.6-52.0)$ & $31.5(29.5-33.6)$ & $12.7(11.2-14.2)$ & $61.3(59.1-63.5)$ \\
\hline Inner regional & $804(24.2)$ & $53.8(50.3-57.2)$ & $35.6(32.3-38.9)$ & $14.9(12.4-17.4)$ & $65.7(62.3-69.0)$ \\
\hline Outer regional/remote & $553(16.6)$ & $51.1(46.9-55.3)$ & $33.2(29.3-37.2)$ & $15.0(12.0-18.1)$ & $63.5(59.4-67.7)$ \\
\hline \multicolumn{6}{|l|}{ Accessibility to treatment } \\
\hline High accessibility & $2616(78.7)$ & $50.5(48.6-52.5)$ & $32.4(30.6-34.2)$ & $13.2(11.9-14.5)$ & $62.0(60.1-63.9)$ \\
\hline Low accessibility & $710(21.4)$ & $52.6(48.9-56.3)$ & $34.3(30.8-37.8)$ & $15.3(12.7-18.0)$ & $65.4(61.8-68.9)$ \\
\hline \multicolumn{6}{|l|}{ Area disadvantages } \\
\hline Least disadvantaged & 737 (22.2) & $47.7(44.1-51.4)$ & $31.8(28.4-35.2)$ & $12.5(10.1-14.9)$ & $58.6(55.0-62.3)$ \\
\hline Middle SES & $2,014(60.6)$ & $51.2(49.0-53.4)$ & $32.8(30.7-34.9)$ & $13.8(12.3-15.4)$ & $63.4(61.2-65.5)$ \\
\hline Most disadvantaged & $575(17.3)$ & $54.5(50.4-58.6)$ & $34.0(30.1-37.9)$ & $14.5(11.6-17.4)$ & $65.6(61.7-69.6)$ \\
\hline
\end{tabular}

$1.95 \%$ confidence intervals $(\mathrm{CI})$ were calculated as mean $\pm 1.96 \mathrm{se} ; 2$. Participants with missing values in stage $(\mathrm{n}=59)$ were excluded from the calculation; 3. Participants with missing values in grade $(n=45)$ were excluded from the calculation; 4 . Participants with missing values in hormone receptors status ( $\mathrm{n}=106$ ) were excluded from the calculation; 5. High severity was defined as either Stage II-IV, or Grade 3, or HR-. Participants with missing values in overall severity ( $\mathrm{n}=167)$ were excluded from the calculation; 6 . BMI: body mass index. Overweight defined as BMI $\geq 25 ; 7$. Unknown values were treated as missing data for the final data analysis and were handled with multiple imputation. 8. HRT: hormone replacement therapy; 9. Including full-time and part-time employment; 10. Married include those living as married, unmarried include those not living as married. 
Table 2 Odds ratios of breast cancer diagnosed with late stage, high grade, or negative hormone receptors by different factors.

\begin{tabular}{|c|c|c|c|c|c|c|}
\hline & \multicolumn{2}{|c|}{ Stage II-IV } & \multicolumn{2}{|c|}{ Grade 3} & \multicolumn{2}{|l|}{ HR- } \\
\hline & $\begin{array}{l}\text { Adjusted OR }{ }^{1} \\
(95 \% \mathrm{CI})\end{array}$ & $\mathrm{p}$-value & $\begin{array}{l}\text { Adjusted OR }{ }^{2} \\
(95 \% \mathrm{CI})\end{array}$ & $\mathrm{p}$-value & $\begin{array}{c}\text { Adjusted } \mathrm{OR}^{3} \\
(95 \% \mathrm{CI})\end{array}$ & p-value \\
\hline Method of detection & & $<0.01$ & & $<0.01$ & & $<0.01$ \\
\hline Screening & 1 & & 1 & & 1 & \\
\hline Symptoms & $3.63(3.09-4.27)$ & $<0.01$ & $2.25(1.91-2.66)$ & $<0.01$ & $2.42(1.92-3.05)$ & $<0.01$ \\
\hline Frequency of screening & & $<0.01$ & & 0.12 & & 0.19 \\
\hline At least two-yearly & 1 & & 1 & & 1 & \\
\hline Infrequently & $1.74(1.39-2.18)$ & $<0.01$ & $1.24(1.00-1.55)$ & 0.05 & $0.93(0.70-1.24)$ & 0.62 \\
\hline None & $1.89(1.48-2.42)$ & $<0.01$ & $1.15(0.91-1.45)$ & 0.25 & $0.74(0.54-1.03)$ & 0.07 \\
\hline Age of diagnosis & & $<0.01$ & & $<0.01$ & & 0.69 \\
\hline $70-79$ & 1 & & 1 & & 1 & \\
\hline $60-69$ & $1.04(0.82-1.33)$ & 0.75 & $1.06(0.81-1.38)$ & 0.67 & $1.12(0.78-1.60)$ & 0.54 \\
\hline $50-59$ & $1.43(1.11-1.84)$ & 0.01 & $1.31(1.00-1.71)$ & 0.05 & $1.19(0.82-1.74)$ & 0.36 \\
\hline$<50$ & $1.62(1.21-2.17)$ & $<0.01$ & $1.62(1.19-2.22)$ & $<0.01$ & $1.02(0.68-1.54)$ & 0.92 \\
\hline \multicolumn{7}{|l|}{ Lifestyle } \\
\hline BMI $^{4}$ & & $<0.01$ & & 0.14 & & \\
\hline Healthy weight & 1 & & 1 & & - & \\
\hline Overweight & $1.43(1.22-1.67)$ & $<0.01$ & $1.13(0.96-1.32)$ & 0.14 & - & \\
\hline Smoking & & 0.01 & & 0.04 & & 0.01 \\
\hline Current smoker & 1 & & 1 & & 1 & \\
\hline Used to smoke & $1.27(0.94-1.71)$ & 0.11 & $1.23(0.91-1.66)$ & 0.18 & $1.14(0.74-1.74)$ & 0.55 \\
\hline Never smoked & $1.40(1.05-1.87)$ & 0.01 & $1.41(1.05-1.88)$ & 0.02 & $1.53(1.02-2.31)$ & 0.04 \\
\hline \multicolumn{7}{|l|}{ Reproductive history } \\
\hline Duration of menstruation & & & & $<0.01$ & & 0.03 \\
\hline$>35$ years & - & - & 1 & & 1 & \\
\hline$\leq 35$ years & - & - & $1.34(1.13-1.59)$ & $<0.01$ & $1.29(1.03-1.62)$ & 0.03 \\
\hline Menopause & & $<0.01$ & & $<0.01$ & & \\
\hline No & 1 & & 1 & & - & - \\
\hline Yes & $1.98(1.57-2.50)$ & $<0.01$ & $1.41(1.13-1.78)$ & $<0.01$ & - & - \\
\hline Age started using contrace & ves & & & & & 0.12 \\
\hline Never used & - & - & - & - & 1 & \\
\hline$\leq 18$ & - & - & - & - & $1.42(0.96-2.10)$ & 0.08 \\
\hline$>18$ & - & - & - & - & $1.13(0.80-1.59)$ & 0.50 \\
\hline Duration of contraceptives & ing & & & $\mathbf{0 . 0 3}$ & & \\
\hline Never or $<2$ years & - & - & 1 & & - & - \\
\hline $2-10$ years & - & - & $1.29(1.04-1.60)$ & 0.02 & - & - \\
\hline$>10$ years & - & - & $1.33(1.07-1.67)$ & 0.01 & - & - \\
\hline \multicolumn{7}{|l|}{ Family history } \\
\hline Relatives with breast or ov & an cancer & & & 0.01 & & \\
\hline $1^{\text {st }}$ degree & - & - & 1 & & - & - \\
\hline $1^{\text {st }} \& 2^{\text {nd }}$ degree & - & - & $1.30(0.93-1.83)$ & 0.12 & - & - \\
\hline $2^{\text {nd }}$ degree & - & - & $1.54(1.16-2.05)$ & $<0.01$ & - & - \\
\hline None & - & - & $1.49(1.15-1.92)$ & $<0.01$ & - & - \\
\hline \multicolumn{7}{|l|}{ Individual SES } \\
\hline Private insurance & & $<0.01$ & & & & \\
\hline Full insurance & 1 & & - & - & - & - \\
\hline No/part insurance & $1.32(1.12-1.54)$ & $<0.01$ & - & - & - & - \\
\hline \multicolumn{7}{|l|}{ Area-level factors } \\
\hline Remoteness & & & & 0.04 & & \\
\hline Major city & - & - & 1 & & - & - \\
\hline Inner regional & - & - & $1.26(1.05-1.52)$ & 0.01 & - & - \\
\hline Outer regional/Remote & - & - & $1.12(0.91-1.38)$ & 0.30 & - & - \\
\hline Accessibility to treatment & & & & & & 0.12 \\
\hline High accessibility & - & - & - & - & 1 & \\
\hline Low accessibility & - & - & - & - & $1.21(0.95-1.55)$ & 0.12 \\
\hline
\end{tabular}

1. Odds ratios were generated using Model 1; 2. Odds ratios were generated using Model 2; 3. Odds ratios were generated using Model 3; 4. BMI: body mass index. Overweight defined as BMI 25 . 
Table 3 Crude percentages and adjusted odds ratios of diagnosed with high severity breast cancer stratified by women detected by screening or symptoms

\begin{tabular}{|c|c|c|c|c|c|c|}
\hline & \multicolumn{3}{|c|}{ By screening } & \multicolumn{3}{|c|}{ By Symptoms } \\
\hline & $\begin{array}{c}\text { Crude } \\
\text { percentage }^{1}\end{array}$ & $\begin{array}{c}\text { Adjusted OR }{ }^{2} \\
(95 \% \mathrm{CI})\end{array}$ & $\begin{array}{c}\mathrm{p}- \\
\text { value }\end{array}$ & $\begin{array}{c}\text { Crude } \\
\text { percentage }\end{array}$ & $\begin{array}{c}\text { Adjusted } \mathrm{OR}^{3} \\
(95 \% \mathrm{CI})\end{array}$ & $\begin{array}{c}\mathrm{p}- \\
\text { value }\end{array}$ \\
\hline Frequency of screening & & & 0.05 & & & $<0.01$ \\
\hline At least two-yearly & 46.1 & 1 & & 72.8 & 1 & \\
\hline Infrequently & 55.8 & $1.45(1.01-2.07)$ & 0.04 & 85.0 & $2.07(1.47-2.90)$ & $<0.01$ \\
\hline None & 56.1 & $1.46(0.91-2.34)$ & 0.12 & 83.2 & $1.95(1.39-2.74)$ & $<0.01$ \\
\hline Age of diagnosis & & & 0.15 & & & 0.11 \\
\hline $70-79$ & 43.9 & 1 & & 74.2 & 1 & \\
\hline $60-69$ & 45.0 & $0.96(0.71-1.30)$ & 0.79 & 75.1 & $1.15(0.75-1.76)$ & 0.52 \\
\hline $50-59$ & 50.6 & $1.15(0.81-1.64)$ & 0.43 & 79.5 & $1.65(1.02-2.69)$ & 0.04 \\
\hline$<50$ & 51.5 & $1.47(0.94-2.29)$ & 0.09 & 80.3 & $1.73(1.00-2.99)$ & 0.05 \\
\hline \multicolumn{7}{|l|}{ Lifestyle } \\
\hline $\mathrm{BMI}^{4}$ & & & 0.10 & & & $<0.01$ \\
\hline Healthy weight & 44.1 & 1 & & 73.1 & 1 & \\
\hline Overweight & 49.1 & $1.20(0.97-1.49)$ & 0.10 & 82.2 & $1.67(1.31-2.14)$ & $<0.01$ \\
\hline Smoking & & & 0.02 & & & \\
\hline Current smoker & 38.0 & 1 & & - & - & - \\
\hline Used to smoke & 46.7 & $1.52(0.99-2.36)$ & 0.06 & - & - & - \\
\hline Never smoked & 49.0 & $1.77(1.16-2.71)$ & 0.01 & - & - & - \\
\hline \multicolumn{7}{|l|}{ Reproductive history } \\
\hline Menopause & & & $<0.01$ & & & $<0.01$ \\
\hline No & 39.7 & 1 & & 74.2 & 1 & \\
\hline Yes & 48.6 & $2.01(1.42-2.84)$ & $<0.01$ & 79.5 & $2.01(1.43-2.82)$ & $<0.01$ \\
\hline Duration of HRT $^{5}$ & & & & & & 0.04 \\
\hline$>10$ years & - & - & - & 67.5 & 1 & \\
\hline $2-10$ years & - & - & - & 71.1 & $1.10(0.66-1.82)$ & 0.72 \\
\hline Never or $<2$ years & - & - & - & 80.1 & $1.60(1.02-2.51)$ & 0.04 \\
\hline \multicolumn{7}{|l|}{ Individual SES } \\
\hline Education & & & & & & 0.15 \\
\hline$<$ High school & - & - & & 74.9 & 1 & \\
\hline High school/certificate & - & - & & 80.3 & $1.35(0.98-1.85)$ & 0.07 \\
\hline$\geq$ Diploma & - & - & & 78.6 & $1.29(0.94-1.76)$ & 0.12 \\
\hline Employment & & & $<0.01$ & & & 0.08 \\
\hline Unemployed/retired & 42.5 & 1 & & 78.4 & 1 & \\
\hline Employed & 52.1 & $1.46(1.15-1.85)$ & $<0.01$ & 78.2 & $0.75(0.54-1.03)$ & 0.08 \\
\hline Private insurance & & & 0.08 & & & \\
\hline Full insurance & 46.1 & 1 & & - & - & - \\
\hline No/part insurance & 50.2 & $1.22(0.98-1.51)$ & 0.08 & - & - & - \\
\hline \multicolumn{7}{|l|}{ Area-level factors } \\
\hline Remoteness & & & 0.17 & & & \\
\hline Major city & 45.5 & 1 & & - & - & - \\
\hline Inner regional & 50.9 & $1.26(0.99-1.60)$ & 0.07 & - & - & - \\
\hline Outer regional/remote & 49.3 & $1.13(0.86-1.49)$ & 0.37 & - & - & - \\
\hline
\end{tabular}




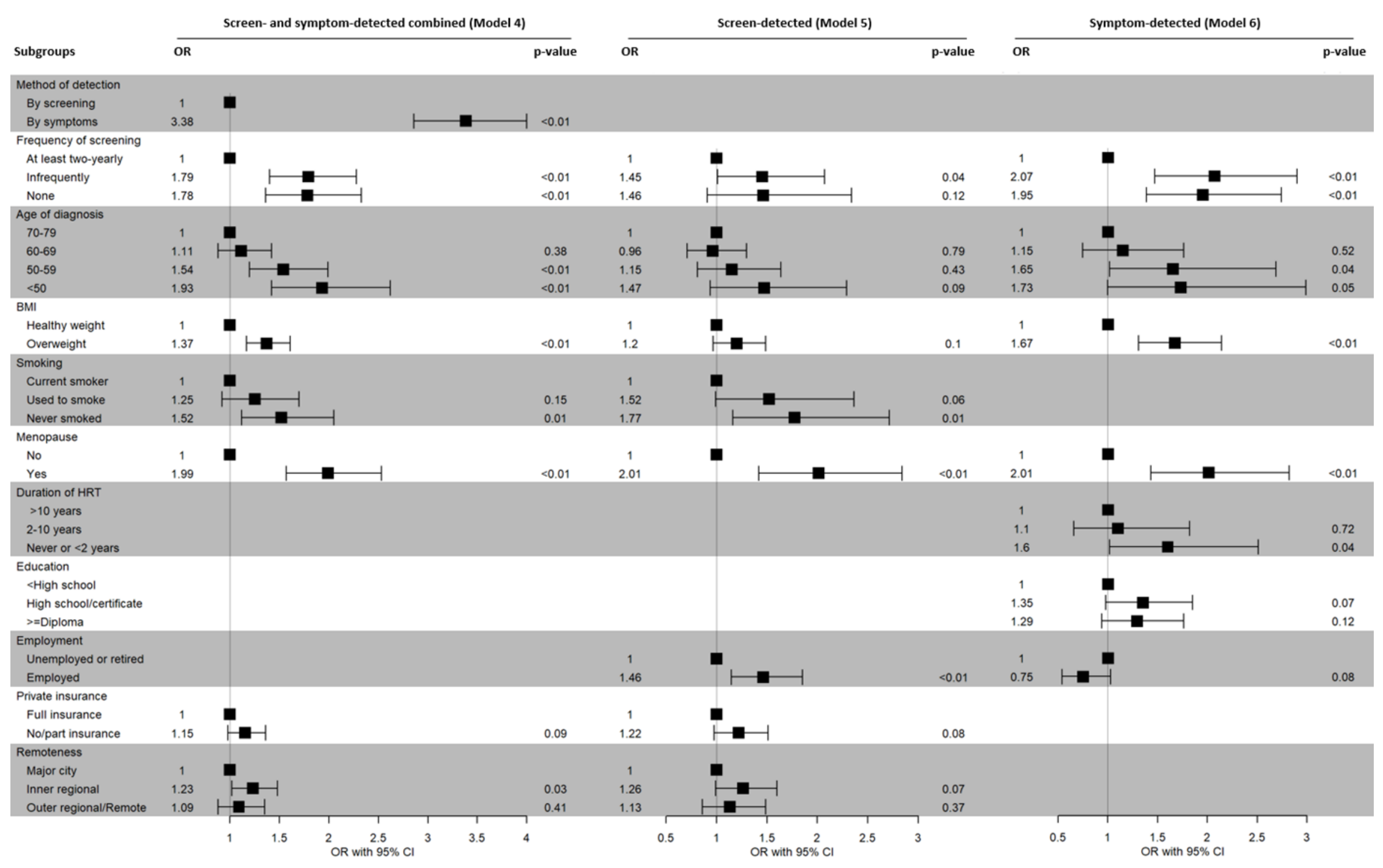

Figure 1 Odds ratios of high severity breast cancer at diagnosis by detection methods. 
Supplementary Table 1 Adjusted odds ratios of diagnosed with high severity breast cancer stratified by screening facilities among women detected by screening

\begin{tabular}{|c|c|c|c|c|}
\hline & \multicolumn{2}{|c|}{ Screened in Public Facilities } & \multicolumn{2}{|c|}{ Screened in Private Facilities } \\
\hline & $\begin{array}{c}\text { Adjusted OR }{ }^{1} \\
(95 \% \mathrm{CI})\end{array}$ & p-value & $\begin{array}{l}\text { Adjusted OR }{ }^{2} \\
(95 \% \mathrm{CI})\end{array}$ & $\mathrm{p}$-value \\
\hline Frequency of screening & & 0.10 & & 0.43 \\
\hline At least two-yearly & 1 & & 1 & \\
\hline Infrequently & $1.41(0.95-2.11)$ & 0.09 & $1.74(0.74-4.08)$ & 0.21 \\
\hline None & $1.46(0.91-2.34)$ & 0.13 & $1.21(0.51-2.86)$ & 0.67 \\
\hline Age of diagnosis & & 0.02 & & 0.74 \\
\hline $70-79$ & 1 & & 1 & \\
\hline $60-69$ & $0.89(0.63-1.26)$ & 0.53 & $1.14(0.57-2.27)$ & 0.71 \\
\hline $50-59$ & $1.24(0.83-1.85)$ & 0.29 & $0.84(0.38-1.82)$ & 0.65 \\
\hline$<50$ & $1.74(1.03-2.92)$ & 0.04 & $0.93(0.37-2.36)$ & 0.88 \\
\hline \multicolumn{5}{|l|}{ Lifestyle } \\
\hline BMI $^{3}$ & & $<0.01$ & & 0.14 \\
\hline Healthy weight & 1 & & 1 & \\
\hline Overweight & $1.46(1.13-1.88)$ & $<0.01$ & $0.72(0.46-1.11)$ & 0.14 \\
\hline Smoking & & 0.16 & & 0.13 \\
\hline Current smoker & 1 & & 1 & \\
\hline Used to smoke & $1.42(0.87-2.30)$ & 0.16 & $1.66(0.55-4.98)$ & 0.37 \\
\hline Never smoked & $1.56(0.98-2.50)$ & 0.06 & $2.35(0.80-6.86)$ & 0.12 \\
\hline \multicolumn{5}{|l|}{ Reproductive history } \\
\hline Menopause & & $<0.01$ & & $<0.01$ \\
\hline No & 1 & & 1 & \\
\hline Yes & $1.81(1.21-2.73)$ & $<0.01$ & $2.81(1.41-5.60)$ & $<0.01$ \\
\hline \multicolumn{5}{|l|}{ Individual SES } \\
\hline Employment & & 0.07 & & $<0.01$ \\
\hline Unemployed/retired & 1 & & 1 & \\
\hline Employed & $1.29(0.98-1.70)$ & 0.07 & $2.24(1.37-3.66)$ & $<0.01$ \\
\hline Private insurance & & 0.50 & & 0.01 \\
\hline Full insurance & 1 & & 1 & \\
\hline No/part insurance & $1.09(0.85-1.38)$ & 0.50 & $2.10(1.18-3.73)$ & 0.01 \\
\hline \multicolumn{5}{|l|}{ Area-level factors } \\
\hline Remoteness & & 0.41 & & 0.11 \\
\hline Major city & 1 & & 1 & \\
\hline Inner regional & $1.16(0.88-1.53)$ & 0.29 & $1.66(0.96-2.88)$ & 0.07 \\
\hline Outer regional/remote & $1.18(0.88-1.59)$ & 0.27 & $0.72(0.31-1.71)$ & 0.46 \\
\hline
\end{tabular}

1. Odds ratios were generated using Model 7, Model 7 used the same variables included in Model 5; 2. Odds ratios were generated using Model 8, Model 8 used the same variables included in Model 5; 3. BMI: body mass index. Overweight defined as $B M I \geq 25$. 


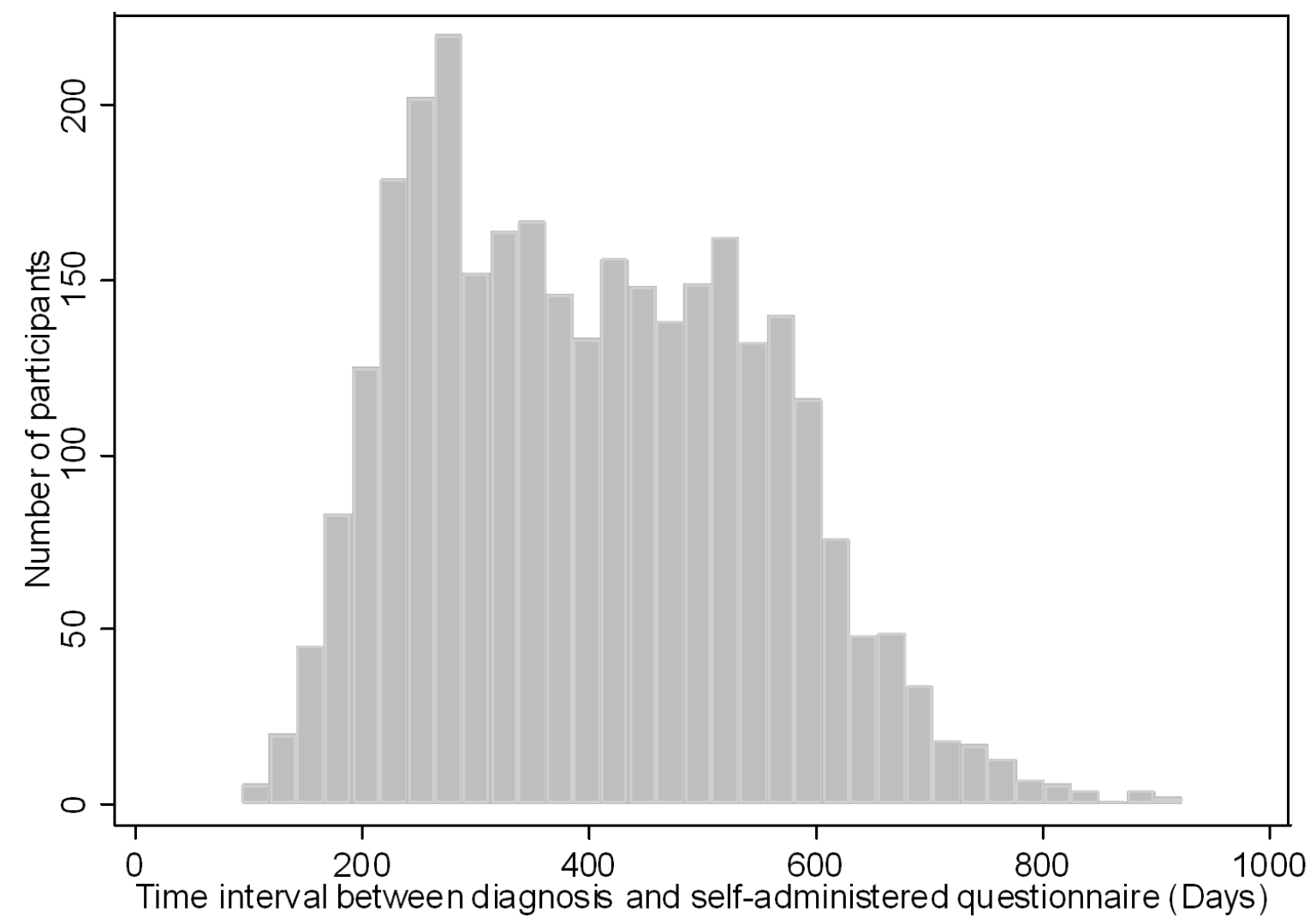

Supplementary Figure 1 Time interval between diagnosis and the returning of self-administered questionnaire. 


\section{References}

1. Yu XQ, Luo Q, Kahn C, O'Connell DL, Houssami N (2015) Temporal trends show improved breast cancer survival in Australia but widening urban-rural differences. The Breast 24 (4):524-527

2. Kou K, Dasgupta P, Cramb SM, Xue QY, Andersson TM-L, Baade PD (2020) Temporal trends in loss of life expectancy after a cancer diagnosis among the Australian population. Cancer Epidemiol 65:101686

3. Youlden DR, Cramb SM, Dunn NA, Muller JM, Pyke CM, Baade PD (2012) The descriptive epidemiology of female breast cancer: an international comparison of screening, incidence, survival and mortality. Cancer Epidemiol 36 (3):237-248

4. Australian Institute of Health and Welfare (2019) Cancer in Australia 2019. Cancer series no.119. Cat. no. CAN 123. Canberra: AIHW.

5. Desmedt C, Haibe-Kains B, Wirapati P, Buyse M, Larsimont D, Bontempi G, Delorenzi M, Piccart M, Sotiriou C (2008) Biological processes associated with breast cancer clinical outcome depend on the molecular subtypes. Clin Cancer Res 14 (16):5158-5165

6. Rosenberg J, Chia YL, Plevritis S (2005) The effect of age, race, tumor size, tumor grade, and disease stage on invasive ductal breast cancer survival in the US SEER database. Breast Cancer Res Treat 89 (1):47-54

7. Henry NL, Shah PD, Haider I, Freer PE, Jagsi R, Sabel MS. Chapter 88: Cancer of the Breast. In: Niederhuber JE, Armitage JO, Doroshow JH, Kastan MB, Tepper JE, eds. Abeloff's Clinical Oncology. 6th ed. Philadelphia, Pa: Elsevier; 2020.

8. Jagsi R, King TA, Lehman C, Morrow M, Harris JR, Burstein HJ. Chapter 79: Malignant Tumors of the Breast. In: DeVita VT, Lawrence TS, Lawrence TS, Rosenberg SA, eds. DeVita, Hellman, and Rosenberg's Cancer: Principles and Practice of Oncology. 11th ed. Philadelphia, Pa: Lippincott Williams \& Wilkins; 2019.

9. Baade PD, Turrell G, Aitken JF (2011) Geographic remoteness, area-level socio-economic disadvantage and advanced breast cancer: a cross-sectional, multilevel study. J Epidemiol Community Health 65 (11):1037-1043. doi:10.1136/jech.2010.114777

10. Bastiaannet E, Liefers G, De Craen A, Kuppen P, Van De Water W, Portielje J, Van Der Geest L, Janssen-Heijnen M, Dekkers O, Van De Velde C (2010) Breast cancer in elderly compared to younger patients in the Netherlands: stage at diagnosis, treatment and survival in 127,805 unselected patients. Breast Cancer Res Treat 124 (3):801-807

11. Cui Y, Whiteman MK, Flaws JA, Langenberg P, Tkaczuk KH, Bush TL (2002) Body mass and stage of breast cancer at diagnosis. Int J Cancer 98 (2):279-283

12. Hoffman M, De Pinho H, Cooper D, Sayed R, Dent D, Gudgeon A, van Zyl J, Rosenberg L, Shapiro S (2000) Breast cancer incidence and determinants of cancer stage in the Western Cape. Population (N) 540:U6079

13. Osborne C, Ostir GV, Du X, Peek MK, Goodwin JS (2005) The influence of marital status on the stage at diagnosis, treatment, and survival of older women with breast cancer. Breast Cancer Res Treat 93 (1):41-47

14. Coughlin SS (2019) Social determinants of breast cancer risk, stage, and survival. Breast Cancer Res Treat 177(3):537-548 
15. Hahn KM, Bondy ML, Selvan M, Lund MJ, Liff JM, Flagg EW, Brinton LA, Porter P, Eley JW, Coates RJ (2007) Factors associated with advanced disease stage at diagnosis in a population-based study of patients with newly diagnosed breast cancer. Am J Epidemiol 166 (9):1035-1044

16. Franzoi MA, Schwartsmann G, de Azevedo SJ, Geib G, Zaffaroni F, Liedke PE (2019) Differences in Breast Cancer Stage at Diagnosis by Ethnicity, Insurance Status, and Family Income in Young Women in the USA. J Racial Ethn Health Disparities 6(5):909-916

17. Australian Institute of Health and Welfare (2015) BreastScreen Australia monitoring report 2012-2013. Vol Cancer series no. 95. Cat. no. CAN 93. Canberra: AIHW.

18. Cancer Australia (2015) Early detection of breast cancer.

https://canceraustralia.gov.au/publications-and-resources/position-statements/early-detectionbreast-cancer. Accessed 25 August 2020

19. Health Institute of Health and Welfare (2018) BreastScreen Australia monitoring report 2018. Vol Cancer series no. 112. Cat. no. CAN 116. Canberra: AIHW.

20. Youl PH, Baade PD, Aitken JF, Chambers SK, Turrell G, Pyke C, Dunn J (2011) A multilevel investigation of inequalities in clinical and psychosocial outcomes for women after breast cancer. BMC Cancer 11 (1):415

21. Youl P, Aitken J, Turrell G, Chambers S, Dunn J, Pyke C, Baade P (2016) The impact of rurality and disadvantage on the diagnostic interval for breast cancer in a large populationbased study of 3202 women in Queensland, Australia. Int J Environ Res Public Health 13 (11): 1156

22. Willcox S (2001) Promoting private health insurance in Australia. Health Aff (Millwood) 20 (3):152-161. doi:10.1377/hlthaff.20.3.152

23. Edge SB, Byrd DR, Carducci MA, Compton CC, Fritz A, Greene F (2010) AJCC cancer staging manual, vol 7. Springer New York

24. Health Institute of Health and Welfare (2004) Rural, regional and remote health: a guide to remoteness classifications. AIHW Canberra, Australia

25. Baade PD, Dasgupta P, Aitken JF, Turrell G (2011) Distance to the closest radiotherapy facility and survival after a diagnosis of rectal cancer in Queensland. Med J Aust 195 (6):350354

26. Osborne CK (1998) Steroid hormone receptors in breast cancer management. Breast Cancer Res Treat 51 (3):227-238. doi:10.1023/A:1006132427948

27. Louie MC, Sevigny MB (2017) Steroid hormone receptors as prognostic markers in breast cancer. Am J Cancer Res 7 (8):1617-1636

28. Derksen S, Keselman HJ (1992) Backward, forward and stepwise automated subset selection algorithms: Frequency of obtaining authentic and noise variables. Br J Math Stat Psychol 45 (2):265-282

29. Rubin DB (1987) Multiple imputation for survey nonresponse. Wiley, New York

30. White IR, Royston P, Wood AM (2011) Multiple imputation using chained equations: issues and guidance for practice. Stat Med 30 (4):377-399

31. Lam M, Kwok C, Lee MJ (2018) Prevalence and sociodemographic correlates of routine breast cancer screening practices among migrant-Australian women. Aust N Z J Public

Health 42 (1):98-103 
32. Leung J, McKenzie S, Martin J, Dobson A, McLaughlin D (2014) Longitudinal patterns of breast cancer screening: mammography, clinical, and breast self-examinations in a rural and urban setting. Womens Health Issues 24 (1):e139-e146

33. Aarts MJ, Voogd AC, Duijm LE, Coebergh JW, Louwman WJ (2011) Socioeconomic inequalities in attending the mass screening for breast cancer in the south of the Netherlands-associations with stage at diagnosis and survival. Breast Cancer Res Treat 128 (2):517-525.

34. Abdel-Rahman O (2019) Impact of NCI Socioeconomic Index on the Outcomes of Nonmetastatic Breast Cancer Patients: Analysis of SEER Census Tract-Level Socioeconomic Database. Clin Breast Cancer. doi:10.1016/j.clbc.2019.06.013

35. Abdelsattar ZM, Hendren S, Wong SL (2017) The impact of health insurance on cancer care in disadvantaged communities. Cancer 123 (7):1219-1227. doi:10.1002/cncr.30431

36. Agarwal S, Ying J, Boucher KM, Agarwal JP (2017) The association between socioeconomic factors and breast cancer-specific survival varies by race. PLoS One 12 (12):e0187018. doi:10.1371/journal.pone.0187018

37. Akinyemiju T, Moore JX, Ojesina AI, Waterbor JW, Altekruse SF (2016) Racial disparities in individual breast cancer outcomes by hormone-receptor subtype, area-level socio-economic status and healthcare resources. Breast Cancer Res Treat 157 (3):575-586.

38. Akinyemiju TF, Soliman AS, Johnson NJ, Altekruse SF, Welch K, Banerjee M, Schwartz K, Merajver S (2013) Individual and neighborhood socioeconomic status and healthcare resources in relation to black-white breast cancer survival disparities. J Cancer Epidemiol 2013:490472.

39. Dasgupta P, Baade PD, Aitken JF, Turrell G (2012) Multilevel determinants of breast cancer survival: association with geographic remoteness and area-level socioeconomic disadvantage. Breast Cancer Res Treat 132 (2):701-710.

40. Yu XQ (2009) Socioeconomic disparities in breast cancer survival: relation to stage at diagnosis, treatment and race. BMC Cancer 9 (1):364

41. Gordon NH (1995) Association of education and income with estrogen receptor status in primary breast cancer. Am J Epidemiol 142 (8):796-803

42. Macleod U, Ross S, Gillis C, McConnachie A, Twelves C, Watt G (2000) Socioeconomic deprivation and stage of disease at presentation in women with breast cancer. Ann Oncol 11 (1):105-107

43. Espina C, McKenzie F, Dos-Santos-Silva I (2017) Delayed presentation and diagnosis of breast cancer in African women: a systematic review. Ann Epidemiol 27 (10):659-671.e7.

44. Baade PD, Dasgupta P, Youl PH, Pyke C, Aitken JF (2016) Geographical Inequalities in Surgical Treatment for Localized Female Breast Cancer, Queensland, Australia 1997-2011: Improvements over Time but Inequalities Remain. Int J Environ Res Public Health 13 (7):729. doi:10.3390/ijerph13070729

45. Roder D, Zorbas HM, Kollias J, Pyke CM, Walters D, Campbell ID, Taylor C, Webster F (2014) Analysing risk factors for poorer breast cancer outcomes in residents of lower socioeconomic areas of Australia. Aust Health Rev 38 (2):134-141

46. Dalton SO, Düring M, Ross L, Carlsen K, Mortensen PB, Lynch J, Johansen C (2006) The relation between socioeconomic and demographic factors and tumour stage in women diagnosed with breast cancer in Denmark, 1983-1999. Br J Cancer 95 (5):653 
47. Breast cancer awareness month. https://canceraustralia.gov.au/about-us/campaignsevents/breast-cancer-awareness-month. Accessed 25 August 2020

48. Breast Aware Australia. http://www.breastawareaustralia.com.au/. Accessed 25 August 2020

49. Lyle G, Hendrie GA, Hendrie D (2017) Understanding the effects of socioeconomic status along the breast cancer continuum in Australian women: a systematic review of evidence. Int J Equity Health.16 (1):182

50. Akinyemiju TF, Pisu M, Waterbor JW, Altekruse SF (2015) Socioeconomic status and incidence of breast cancer by hormone receptor subtype. Springerplus 4:508.

doi:10.1186/s40064-015-1282-2

51. Sineshaw HM, Gaudet M, Ward EM, Flanders WD, Desantis C, Lin CC, Jemal A (2014) Association of race/ethnicity, socioeconomic status, and breast cancer subtypes in the National Cancer Data Base (2010-2011). Breast Cancer Res Treat 145 (3):753-763

52. Parise CA, Bauer KR, Brown MM, Caggiano V (2009) Breast Cancer Subtypes as Defined by the Estrogen Receptor (ER), Progesterone Receptor (PR), and the Human Epidermal Growth Factor Receptor 2 (HER2) among Women with Invasive Breast Cancer in California, 1999-2004. The Breast Journal 15 (6):593-602. doi:10.1111/j.15244741.2009.00822.x

53. Imkampe AK, Bates T (2012) Correlation of age at oral contraceptive pill start with age at breast cancer diagnosis. Breast J 18 (1):35-40. doi:10.1111/j.1524-4741.2011.01181.x

54. Kelsey JL, Gammon MD, John EM (1993) Reproductive factors and breast cancer. Epidemiol Rev 15 (1):36

55. McPherson K, Steel C, Dixon J (2000) Breast cancer-epidemiology, risk factors, and genetics. BMJ 321 (7261):624-628

56. Loman N, Johannsson O, Kristoffersson U, Olsson Hk, Borg Ak (2001) Family history of breast and ovarian cancers and BRCA1 and BRCA2 mutations in a population-based series of early-onset breast cancer. J Natl Cancer Inst 93 (16):1215-1223

57. Humpel N, Jones SC (2004) 'I don't really know, so it's a guess': women's reasons for breast cancer risk estimation. Asian Pac J Cancer Prev 5(4):428-32

58. Klauber-DeMore N (2006) Tumor biology of breast cancer in young women. Breast Dis 23 (1):9-15

59. Checka CM, Chun JE, Schnabel FR, Lee J, Toth H (2012) The relationship of mammographic density and age: implications for breast cancer screening. AJR Am J Roentgenol 198 (3):W292-5

60. Morrell S, Barratt A, Irwig L, Howard K, Biesheuvel C, Armstrong B (2010) Estimates of overdiagnosis of invasive breast cancer associated with screening mammography. Cancer Causes Control 21 (2):275-282

61. Fanshawe T, Oke J (2020) Cancer statistics A survival guide. Significance 17 (1)

62. Welch HG, Black WC (2010) Overdiagnosis in cancer. J Natl Cancer Inst 102 (9):605613 